RESIDENT

\& FELLOW

SECTION

Section Editor

Mitchell S.V. Elkind,

MD, MS

Thy P. Nguyen, MD

Lisa M. El-Hakam, MD

Address correspondence and reprint requests to Dr. Lisa $\mathrm{M}$. El-Hakam, Department of Pediatrics, Division of Child Neurology, Baylor College of Medicine, Texas Children's Hospital, 6621 Fannin

St. CC 950.04, Houston, TX 77030-2399

\title{
Clinical Reasoning: A 9-year-old girl with seizures and encephalopathy
}

\section{SECTION 1}

A 9-year-old girl presented to the emergency department with seizures and altered mental status. Her seizures were characterized by left eye deviation and head version followed by generalized tonic-clonic movements. She received $20 \mathrm{mg}$ of phenytoin equivalents per kilogram of IV fosphenytoin and $4 \mathrm{mg}$ of IV lorazepam. She was febrile $\left(102^{\circ} \mathrm{F}\right)$, but otherwise had normal vital signs. On examination, she was lethargic without focal cranial nerve findings or weakness. She experienced mood lability and visual hallucinations, but had no further seizures.

She previously had normal development with no decline in cognition or school performance.
She was on levothyroxine for hypothyroidism resulting from prior thyroiditis with a goiter. There were no recent medication changes or infections. Family history included hypothyroidism and lupus; there was no family history of epilepsy or neuropsychiatric disorders.

\section{Questions for consideration:}

1. What is the differential diagnosis for seizures and encephalopathy in a pediatric patient?

2. How do the patients' history and physical examination narrow or broaden the differential diagnosis?

3. What diagnostic tests would you order? 
SECTION 2

The differential diagnosis for seizures with persistent altered mental status includes nonconvulsive

\begin{tabular}{|c|c|c|c|}
\hline \multirow[t]{2}{*}{$\begin{array}{l}\text { child wit } \\
\text { and autc }\end{array}$} & \multirow[t]{2}{*}{$\begin{array}{l}\text { encephalc } \\
\text { mmune thy }\end{array}$} & \multirow[t]{2}{*}{$\begin{array}{l}\text { ory findin } \\
\text { pathy, se } \\
\text { roiditis }\end{array}$} & \multirow[b]{2}{*}{$\begin{array}{l}\text { Reference } \\
\text { values }\end{array}$} \\
\hline & & & \\
\hline $\begin{array}{l}\text { CSF leukocyte cell } \\
\text { count, cells } / \mathrm{mm}^{3}\end{array}$ & 4 & 0 & $0-5$ \\
\hline $\begin{array}{l}\text { CSF erythrocyte } \\
\text { count, cells } / \mathrm{mm}^{3}\end{array}$ & 5 & 0 & 0 \\
\hline CSF protein, mg/dL & 60 & 42 & $15-45$ \\
\hline CSF glucose, $\mathrm{mg} / \mathrm{dL}$ & 88 & 95 & - \\
\hline $\begin{array}{l}\text { CSF myelin basic } \\
\text { protein, } \mathrm{ng} / \mathrm{mL}\end{array}$ & N/A & 0.23 & $0-4$ \\
\hline $\begin{array}{l}\text { CSF oligoclonal } \\
\text { bands }\end{array}$ & N/A & $\mathrm{Neg}$ & $\mathrm{Neg}$ \\
\hline $\begin{array}{l}\text { Thyroid stimulating } \\
\text { hormone, } \mu \mathrm{IU} / \mathrm{mL}\end{array}$ & 3.426 & 5.05 & $0.36-5.8$ \\
\hline $\begin{array}{l}\text { Antithyroglobulin } \\
\text { antibodies, IU/mL }\end{array}$ & 8,225 & 8,069 & $0-40$ \\
\hline $\begin{array}{l}\text { Antithyroperoxidase } \\
\text { antibodies, IU/mL }\end{array}$ & 9,847 & $>1,000$ & $0-34$ \\
\hline $\begin{array}{l}\text { Free thyroxine (T4), } \\
\text { ng/dL }\end{array}$ & 0.8 & 1 & $1-2.4$ \\
\hline
\end{tabular}

status epilepticus, CNS infections, metabolic encephalopathies, structural lesions, toxins, acute disseminated encephalomyelitis, and inflammatory encephalopathies. In this patient, pertinent data included pyrexia, seizures, and thyroiditis. Meningitic doses of antibiotics and acyclovir were initiated on presentation. Evaluation for infections, including chest $\mathrm{x}$-ray, blood cultures, and CSF viral and bacterial cultures, was normal (table). CSF revealed cytoalbuminologic dissociation.

Liver function tests, ammonia, lactate, and electrolytes were normal. Antithyroglobulin and antithyroperoxidase antibodies were elevated. Noncontrast CT of the brain was normal. MRI of the brain with gadolinium was normal. EEG showed generalized slowing without epileptiform abnormalities.

On the second day of hospitalization, the patient remained encephalopathic.

\section{Questions for consideration:}

1. What is the probable diagnosis?

2. Does the normal MRI change the differential?

3. What treatments can be considered at this stage? 


\section{SECTION 3}

After exclusion of other etiologies, the elevated CSF protein, elevated thyroid autoantibodies, and history of Hashimoto thyroiditis suggested an inflammatory encephalopathy. ${ }^{1}$ The patient received a 5-day course of $30 \mathrm{mg} / \mathrm{kg} /$ day of IV methylprednisolone beginning on the second hospital day resulting in rapid improvement. She was discharged home with normal mentation on a steroid taper.

Five months later, she again presented with a seizure and altered mental status, without identifiable triggers. Her vital signs were normal and her neurologic examination showed no focal deficits. She was again encephalopathic with auditory hallucinations. MRI brain with and without gadolinium was unrevealing. CSF studies were normal (table). IV methylprednisolone was initiated at $30 \mathrm{mg} / \mathrm{kg} /$ day for 5 days with resolution of symptoms. She was discharged on a prednisone taper.

DISCUSSION Steroid-responsive encephalopathy associated with autoimmune thyroiditis, also referred to as Hashimoto encephalopathy, is a rare entity first described in $1966 .{ }^{2}$ The improvement with IV methylprednisolone underscores the importance of its recognition. ${ }^{3}$ There is no consensus on diagnostic criteria. Proposed criteria include impaired consciousness, lack of CSF evidence of infection, and high serum level of antithyroid antibodies. ${ }^{3}$

The role of thyroid antibodies as either etiology or epiphenomena remains unknown. One study revealed binding of sera and CSF antithyroperoxidase antibodies to cerebellar astrocytes. ${ }^{4}$ In pediatric Hashimoto encephalopathy, $37.5 \%$ have established diagnoses of Hashimoto thyroiditis. ${ }^{1,5}$ The improvement with glucocorticoids, association with other autoimmune diseases, and elevated CSF protein levels suggest an autoimmune pathophysiology.

Without a known history of Hashimoto thyroiditis, the diagnosis requires a high index of suspicion. ${ }^{6}$ The prevalence of Hashimoto thyroiditis in children is $1.2 \%{ }^{6}$ Antithyroid antibodies in adults are seen in $13.9 \%$ of women and $2.9 \%$ of men. ${ }^{7}$ The prevalence of antithyroid antibodies in children is unknown, but these antibodies occur in $13.9 \%$ of children with type 1 diabetes mellitus. ${ }^{8}$ Other autoimmune diseases, such as pernicious anemia and rheumatoid arthritis, occur in $13.6 \%$ of cases of pediatric Hashimoto encephalopathy. ${ }^{6}$ Despite the family history of lupus, this child had no clinical manifestations of lupus.

Since its initial description in the 1960s, the incidence of Hashimoto encephalopathy has been reported as 2.1 in $100,000 .^{3}$ Only $22 \%$ of all cases occur in children. ${ }^{3}$ Patients may present to a psychiatric ward with neuropsychiatric abnormalities. ${ }^{3}$ Neurologic manifesta- tions include seizures, stroke-like syndromes, ataxia, myoclonus, tremor, hallucinations, amnesia, sensory loss, headaches, and fatigue. ${ }^{3,5}$ Thyroid function tests may appear normal despite the elevation of antithyroid antibodies. ${ }^{1,3,5}$ Subclinical hypothyroidism is the most common thyroid abnormality found in Hashimoto encephalopathy. ${ }^{3}$ Overt hyperthyroidism and hypothyroidism must be ruled out as etiologies of metabolic encephalopathy.

MRI findings in Hashimoto encephalopathy are either nonspecific (49\%) or normal $(51 \%) .{ }^{3}$ In pediatric patients, imaging is normal in $68 \% .^{5}$ Nonspecific findings on MRI include subcortical white matter changes and T2 cortical hyperintensities. ${ }^{3}$ Elevated CSF protein is found in 60\%-78\%., Elevated 14-3-3 has been reported, and Hashimoto encephalopathy is in the differential for CreutzfeldtJakob disease. EEG is abnormal in $98 \%$ but generally shows diffuse slowing. ${ }^{3}$

The age range in the Hashimoto encephalopathy literature is from 6 to 78 years. ${ }^{1,3,5,6,9,10}$ In children, there is an $88 \%$ predominance of affected females with a median age of 13.7 , with $81 \%$ of patients developing seizures. ${ }^{5,6}$ Seizures manifest in $60 \%$ of adults. ${ }^{3}$ Relapses occur in $31 \%$ of children compared to $60 \%$ of adults. ${ }^{3,5,6}$ Focal neurologic findings are not common in pediatric patients. ${ }^{1,5,6,9}$

The pathology is rarely reported. One case had normal autopsy results. ${ }^{2,3}$ Nonspecific lymphocytic infiltration of the vascular walls was found in 2 patients who underwent brain biopsy. ${ }^{3}$ Future pathology studies may allow for elucidation of the disease.

The dramatic response to steroids is considered one of the distinguishing features of the disease. ${ }^{1,2,3,5,6,9,10}$ Relapses may prompt consideration of chronic corticosteroid therapy. ${ }^{6}$ Further studies are needed to establish the role of prednisone.

CONCLUSION Steroid-responsive encephalopathy associated with autoimmune thyroiditis remains a controversial and underdiagnosed condition. ${ }^{1,6}$ Further research is needed on the natural history, treatment, and pathophysiology. Neurologists should have a high index of suspicion in both children and adults because of the rapid and dramatic clinical response to steroids. ${ }^{6}$

\section{DISCLOSURE}

Dr. Nguyen reports no disclosures. Dr. El-Hakam has received research support from the NIH (Child Health Research Career Development Award K12 HD41648). The content is solely the responsibility of the authors and does not necessarily represent the official views of the CHRCDA/NIH.

\section{REFERENCES}

1. Vasconcellos E, Pina-Garza JE, Fakhoury T, Fenichel GM. Pediatric manifestations of Hashimoto's encephalopathy. Pediatr Neurol 1999;20:394-398. 
2. Brain L, Jellinek EH, Ball K. Hashimoto's disease and encephalopathy. Lancet 1966;2:512-514.

3. Chong JY, Rowland LP, Utiger RD. Hashimoto encephalopathy: syndrome or myth? Arch Neurol 2003;60:164-171.

4. Blanchin S, Coffin C, Viader F, et al. Anti-thyroperoxidase antibodies from patients with Hashimoto's encephalopathy bind to cerebellar astrocytes. J Neuroimmunol 2007; 192:13-20.

5. Mahmud FH, Lteif AN, Renaud DL, Reed AM, Brands CK. Steroid-responsive encephalopathy associated with Hashimoto's thyroiditis in an adolescent with chronic hallucinations and depression: case report and review. Pediatrics 2003;112:686-690.

6. Watemberg N, Greenstein D, Levine A. Encephalopathy associated with Hashimoto thyroiditis: pediatric perspective. J Child Neurol 2006;21:1-5.
7. Bjoro T, Holmen J, Kruger O, et al. Prevalence of thyroid disease, thyroid dysfunction and thyroid peroxidase antibodies in a large, unselected population: The Health Study of Nord-Trondelag (HUNT). Eur J Endocrinol 2000;143: 639-647.

8. Mantovani RM, Mantovani LM, Dias VM. Thyroid autoimmunity in children and adolescents with type 1 diabetes mellitus: prevalence and risk factors. J Pediatr Endocrinol Metab 2007;20:669-675.

9. Gayatri NA, Whitehouse WP. Pilot survey of Hashimoto's encephalopathy in children. Dev Med Child Neurol 2005; 47:556-558.

10. Hoffmann F, Reiter K, Kluger G, et al. Seizures, psychosis and coma: severe course of Hashimoto encephalopathy in a six-year-old girl. Neuropediatrics 2007;38: 197-199. 


\section{Neurology}

\section{Clinical Reasoning: A 9-year-old girl with seizures and encephalopathy \\ Thy P. Nguyen and Lisa M. El-Hakam \\ Neurology 2010;74;e97-e100 \\ DOI 10.1212/WNL.0b013e3181e0f75e}

\section{This information is current as of May 31, 2010}

\section{Updated Information \& Services}

Supplementary Material

References

Subspecialty Collections

Permissions \& Licensing

\section{Reprints}

including high resolution figures, can be found at: http://n.neurology.org/content/74/22/e97.full

Supplementary material can be found at: http://n.neurology.org/content/suppl/2010/12/19/74.22.e97.DC1

This article cites 10 articles, 1 of which you can access for free at: http://n.neurology.org/content/74/22/e97.full\#ref-list-1

This article, along with others on similar topics, appears in the following collection(s):

All Cognitive Disorders/Dementia

http://n.neurology.org/cgi/collection/all_cognitive_disorders_dementia All Epilepsy/Seizures

http://n.neurology.org/cgi/collection/all_epilepsy_seizures

All Pediatric

http://n.neurology.org/cgi/collection/all_pediatric

Autoimmune diseases

http://n.neurology.org/cgi/collection/autoimmune_diseases

Neuroendocrinology

http://n.neurology.org/cgi/collection/neuroendocrinology

Information about reproducing this article in parts (figures,tables) or in its entirety can be found online at:

http://www.neurology.org/about/about_the_journal\#permissions

Information about ordering reprints can be found online:

http://n.neurology.org/subscribers/advertise

Neurology ${ }^{\circledR}$ is the official journal of the American Academy of Neurology. Published continuously since 1951, it is now a weekly with 48 issues per year. Copyright . All rights reserved. Print ISSN: 0028-3878. Online ISSN: 1526-632X.

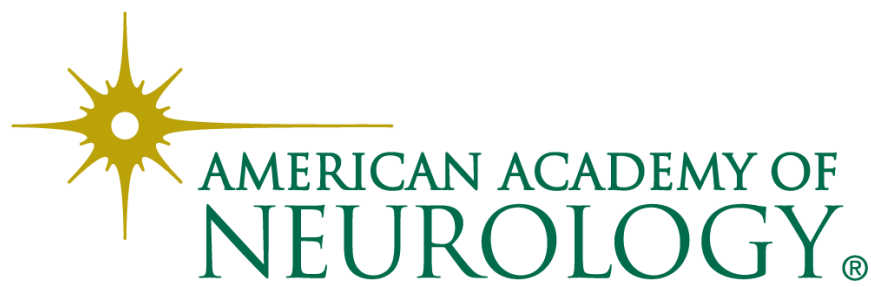

